\title{
Metal-Organic Pt(II) Hexagonal-Prism Macrocycles and Their Photophysical Properties
}

Jian-Hong Tang, ${ }^{\dagger, \downarrow}, \perp$ Ruidong Ni, ${ }^{\S, \perp}$ Yan-Qin He, ${ }^{\dagger, \|, \perp}$ Ryan T. Vanderlinden, ${ }^{\ddagger}$ Yanrong Li, ${ }^{\ddagger}$ Bingbing Shi, ${ }^{\ddagger}$ Zhong-Yu Li, ${ }^{\ddagger}$ Heng Wang, ${ }^{*},{ }^{\S}$ Xiaopeng Li, ${ }^{\S}$ Yue Sun, ${ }^{*}{ }^{\ddagger}$ $\mathrm{Yu}-\mathrm{Wu}$ Zhong, ${ }^{*},+\#$ and Peter J. Stang ${ }^{*}, \dot{*}$

${ }^{\dagger}$ Beijing National Laboratory for Molecular Sciences, Key Laboratory of Photochemistry, CAS Research/Education Center for Excellence in Molecular Sciences, Institute of Chemistry, Chinese Academy of Sciences, Beijing 100190, China

${ }^{\ddagger}$ Department of Chemistry, University of Utah, 315 South 1400 East, Room 2020, Salt Lake City, Utah 84112, United States

${ }^{\S}$ Department of Chemistry, University of South Florida, 4202 East Fowler Avenue, Tampa, Florida 33620, United States

"Institute of BioPharmaceutical Research, Liaocheng University, 1 Hunan Road, Liaocheng, Shandong 252000, China

${ }^{\#}$ School of Chemical Sciences, University of Chinese Academy of Sciences, Beijing 100049, China

${ }^{\perp}$ These authors contributed equally to this work

*Email:

hengwang@mail.usf.edu;

sunyue1956@126.com;

zhongyuwu@iccas.ac.cn;

stang@chem.utah.edu 


\section{General experimental details}

All reagents were commercially available and used as supplied without further purification. ${ }^{1} \mathrm{H}$ NMR and ${ }^{13} \mathrm{C}$ NMR spectra were recorded on a Varian Inova 500 MHz spectrometer. ${ }^{31} \mathrm{P}\left\{{ }^{1} \mathrm{H}\right\}$ NMR spectra were measured on a Varian Unity $300 \mathrm{MHz}$ spectrometer, using an external unlocked sample of $85 \% \mathrm{H}_{3} \mathrm{PO}_{4}(\delta=0)$ as reference. ESI-TOF-MS and TWIM-MS were recorded on a Waters Synapt G2 mass spectrometer. Absorption and fluorescence spectra were recorded on a Hitachi U-4100 and Hitachi F-7000 Spectrophotometer, equipped with $1 \mathrm{~cm}$ quartz cuvettes from Starna Cells, Inc. The emission quantum yield was calculated with quinine sulfate in $0.1 \mathrm{M} \mathrm{H}_{2} \mathrm{SO}_{4}(\Phi=56 \%)$ as reference.

TEM. The sample solutions were drop-casted on to a lacey carbon covered $\mathrm{Cu}$ grid (300 mesh, purchased from Ted Pella Inc.) or carbon-coated $\mathrm{Cu}$ grid (400 mesh, purchased from SPI supplies), and the solution was absorbed by filter paper to avoid aggregation. The TEM images of the drop casted samples were taken with a FEI Morgagni transmission electron microscope.

Collision cross-section calibration. The calibration procedure of Scrivens et $\mathrm{al}^{1}$ was used to convert the drift time scale of the TWIM-MS experiments to a collision cross-section (CCS) scale. The calibration curve was constructed by plotting the corrected CCSs of the molecular ions of CytochromeC against the corrected drift times of the corresponding molecular ions measured in TWIM-MS experiments at the same traveling wave velocity, traveling wave height and ion mobility gas flow settings viz., $1000 \mathrm{~m} / \mathrm{s}, 25 \mathrm{~V}$, and $30 \mathrm{~mL} / \mathrm{min}$, respectively. The database for CCSs of CytochromeC was obtained from Clemmer group webpage. ${ }^{2}$

Molecular modeling. Energy minimization of the self-assembled structures was conducted with the Materials Studio version 4.3 program, using the Anneal and Geometry Optimization tasks in the Forcite module (Accelrys Software, Inc.). All the counterions are omitted. An initially energy-minimized structure was subjected to 5-20 anneal cycles with initial and mid-cycle temperatures of 100 and $500 \mathrm{~K}$, fifty heating ramps per cycle, one hundred dynamics steps per ramp and one dynamics step 
per femtosecond. A constant volume/constant energy (NVE) ensemble was used and the geometry was optimized after each cycle. Geometry optimization used a universal force field with atom-based summation and cubic spline truncation for both the electrostatic and van der Waals parameters. ${ }^{3}$

Synthesis of ligand $\mathbf{1 .}$
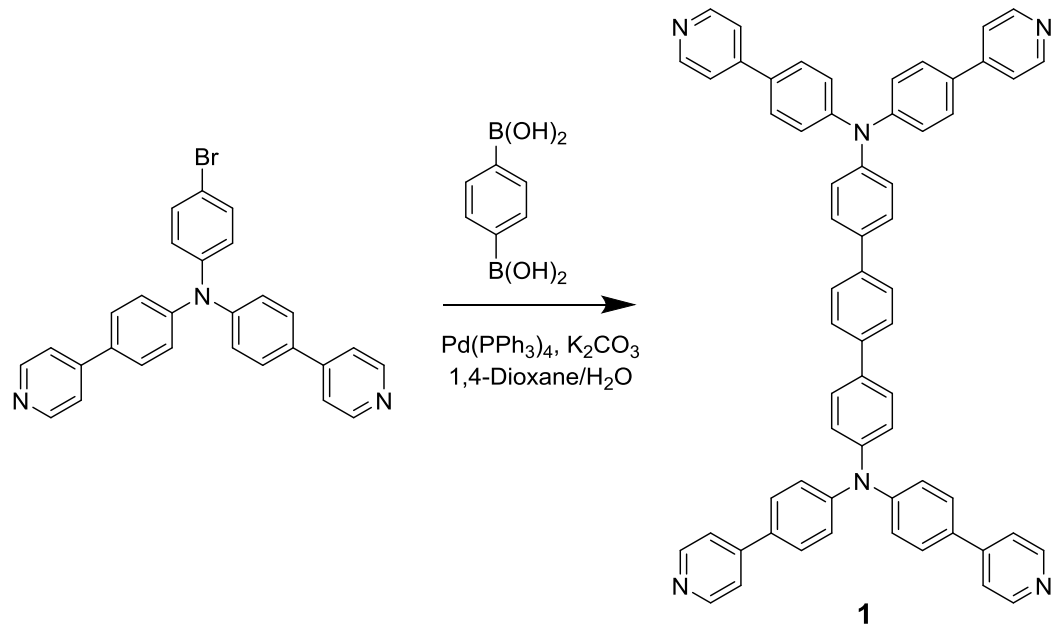

A mixture of 4-bromo- $N, N$-bis(p-(pyrid-4-yl)phenyl)aniline (1.44 g, $3 \mathrm{mmol}$ ), 1,4-phenylenebisboronic acid (165.8 mg, $1 \mathrm{mmol}), \mathrm{Pd}\left(\mathrm{PPh}_{3}\right)_{4}(115.6 \mathrm{mg}, 0.10 \mathrm{mmol})$ and $\mathrm{K}_{2} \mathrm{CO}_{3}(1.66 \mathrm{~g}, 12.0 \mathrm{mmol})$ in 1,4-dioxane $/ \mathrm{H}_{2} \mathrm{O}(30 \mathrm{~mL} / 15 \mathrm{~mL})$ was refluxed at $100{ }^{\circ} \mathrm{C}$ for $48 \mathrm{~h}$ under $\mathrm{N}_{2}$ atmosphere. After cooling to room temperature, the system was extracted with dichloromethane $(3 \times 50 \mathrm{~mL})$. The combined organic layers were concentrated under vacuum and purified with flash column chromatography on silica gel (eluent: ethyl acetate/methanol, 50/50, v/v). $340 \mathrm{mg}$ yellow solid product 2 was isolated in 39\% yield. ${ }^{1} \mathrm{H}$ NMR $\left(500 \mathrm{MHz}, \mathrm{CDCl}_{3}\right): \delta 8.66(\mathrm{~s}, 8 \mathrm{H}), 7.69(\mathrm{~s}, 4 \mathrm{H})$, 7.59-7.63 (m, overlapped, 12H), 7.51 (d, $J=4.5 \mathrm{~Hz}, 8 \mathrm{H}), 7.26-7.29$ (m, overlapped, 12H). ${ }^{13} \mathrm{C} \mathrm{NMR}\left(125 \mathrm{MHz}, \mathrm{CDCl}_{3}\right): \delta 150.28,148.14,147.59,146.17,139.05,136.13$, 132.35, 129.00, 128.19, 127.92, 127.11, 125.36, 124.22, 120.96. ESI-TOF-MS calcd for $[\mathrm{M}+\mathrm{H}]^{+} \mathrm{C}_{64} \mathrm{H}_{45} \mathrm{~N}_{6}(\mathrm{~m} / \mathrm{z})$ : 873.3706. Found: 873.3687. Mp 176-178 ${ }^{\circ} \mathrm{C}$. 


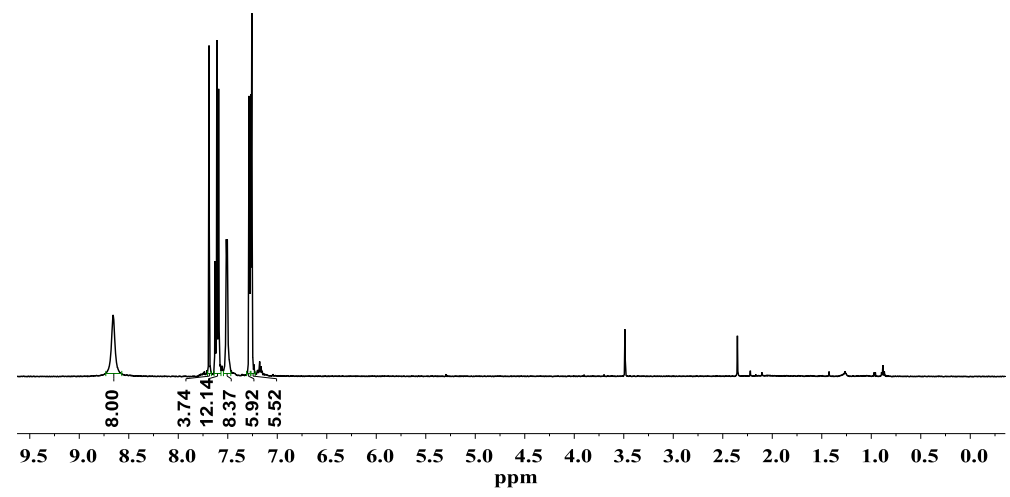

Figure S1. ${ }^{1} \mathrm{H}$ NMR spectrum of $\mathbf{1}$ in $\mathrm{CDCl}_{3}$.

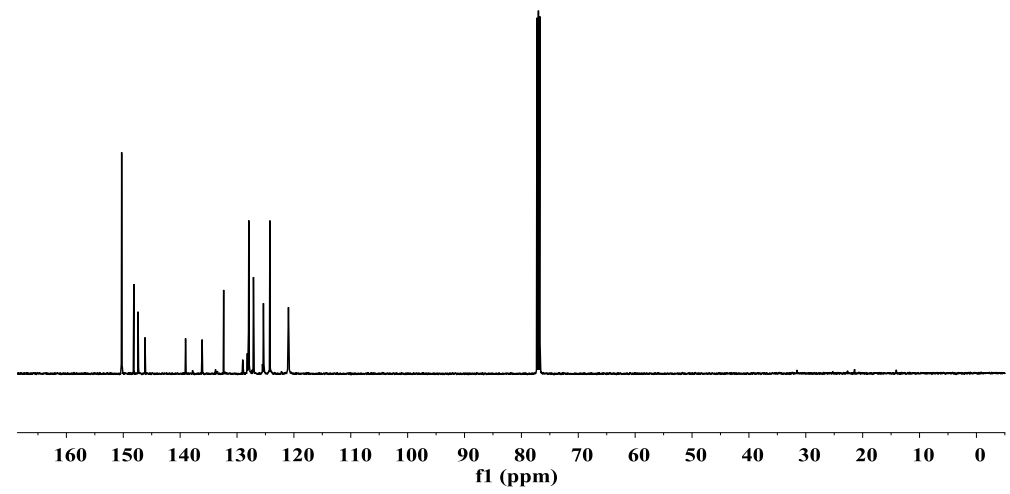

Figure S2. ${ }^{13} \mathrm{C}$ NMR spectrum of $\mathbf{1}$ in $\mathrm{CDCl}_{3}$. 


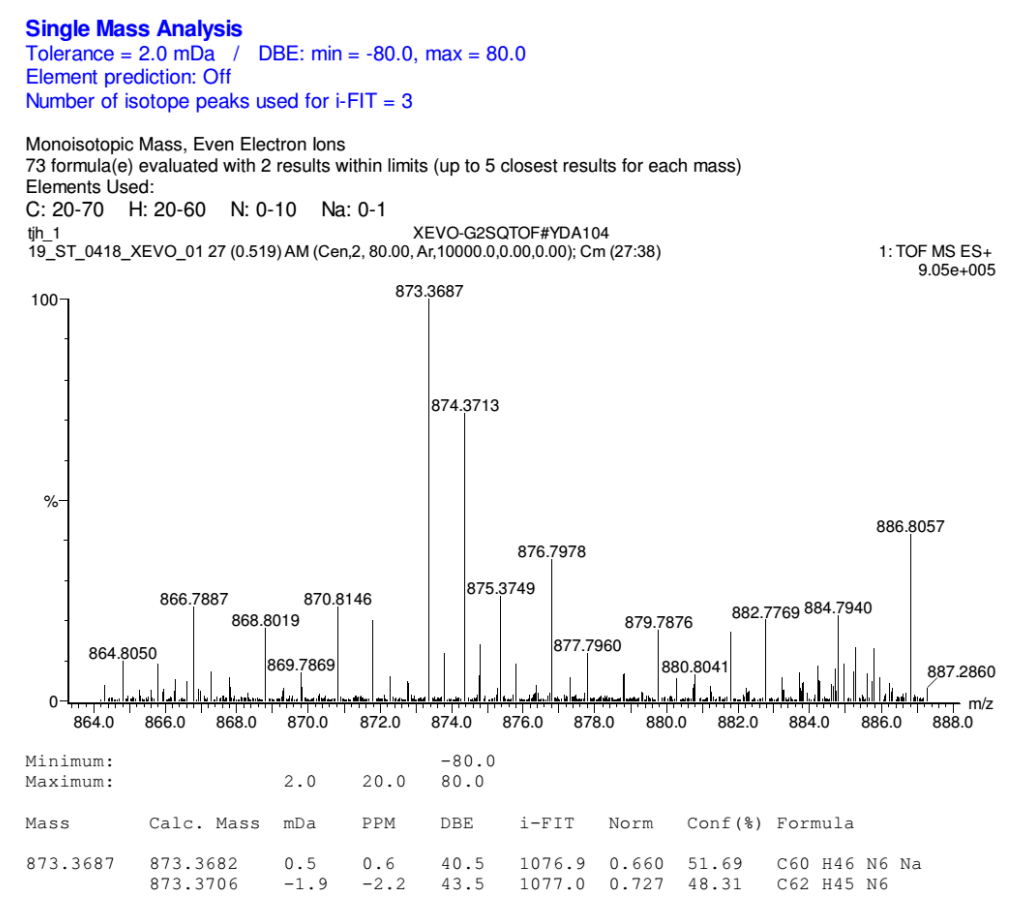

Figure S3. HR-ESI-MS of $\mathbf{1}$.

Synthesis of ligand 2.
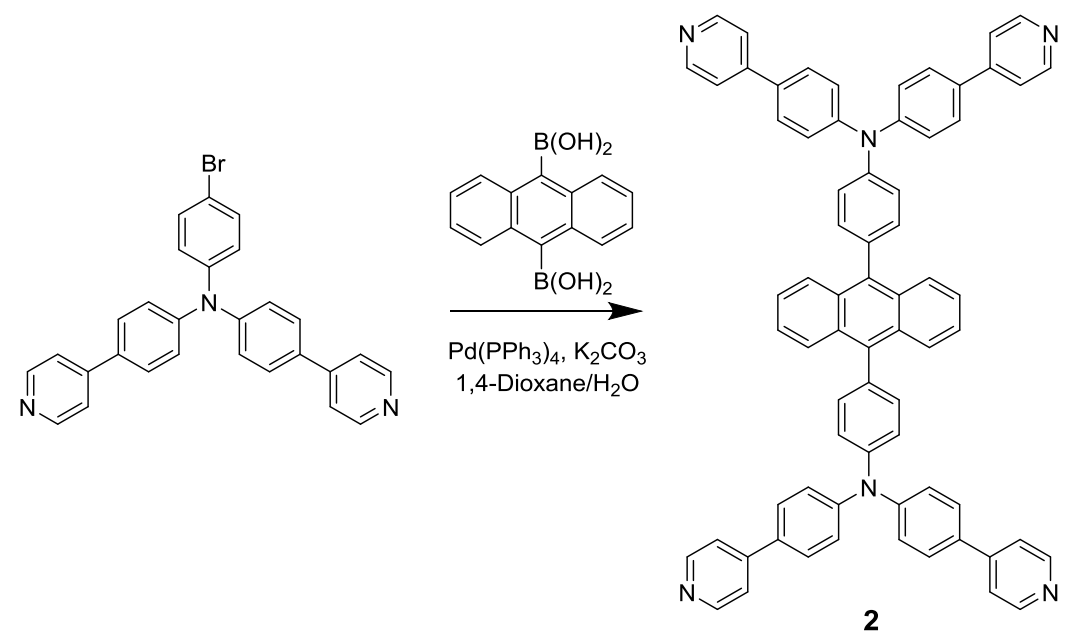

Compound 2 was prepared under the similar procedure for the synthesis of $\mathbf{1}$. The isolated yield is $26 \%(253 \mathrm{mg}) .{ }^{1} \mathrm{H}$ NMR $\left(500 \mathrm{MHz}, \mathrm{CDCl}_{3}\right): \delta 8.65(\mathrm{~d}, J=6.0 \mathrm{~Hz}$, 8H), $7.84(\mathrm{dd}, J=3.0 \mathrm{~Hz}, 4 \mathrm{H}), 7.66(\mathrm{~d}, J=8.5 \mathrm{~Hz}, 8 \mathrm{H}), 7.59(\mathrm{~d}, J=8.5 \mathrm{~Hz}, 2 \mathrm{H}), 7.52$ $(\mathrm{d}, J=6.5 \mathrm{~Hz}, 8 \mathrm{H}), 7.47(\mathrm{~d}, J=6.5 \mathrm{~Hz}, 2 \mathrm{H}), 7.40-7.45$ (m, overlapped, $16 \mathrm{H}) .{ }^{13} \mathrm{C}$ NMR (125 MHz, $\left.\mathrm{CDCl}_{3}\right): \delta 150.31,148.27,147.42,146.18,136.60,134.38,132.52$, 132.49, 130.07, 129.20, 128.17, 128.04, 126.96, 125.18, 124.65, 124.45, 120.98 . 
ESI-TOF-MS calcd for $[\mathrm{M}+\mathrm{H}]^{+} \mathrm{C}_{70} \mathrm{H}_{49} \mathrm{~N}_{6}(\mathrm{~m} / \mathrm{z})$ : 973.4019. Found: 973.3996. Mp $190-192{ }^{\circ} \mathrm{C}$.

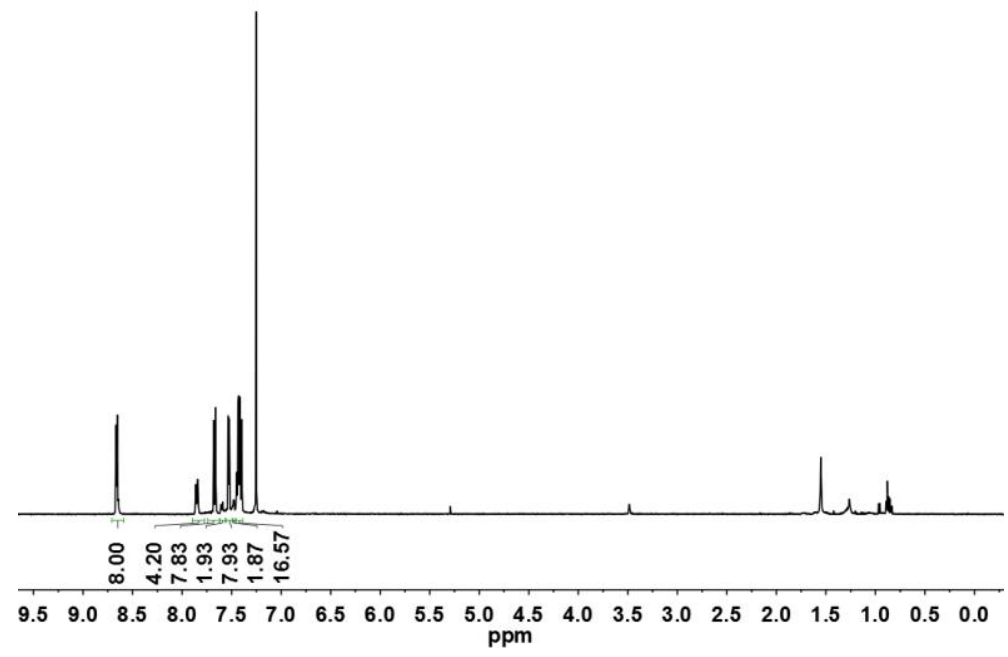

Figure S4. ${ }^{1} \mathrm{H}$ NMR spectrum of $\mathbf{2}$ in $\mathrm{CDCl}_{3}$.

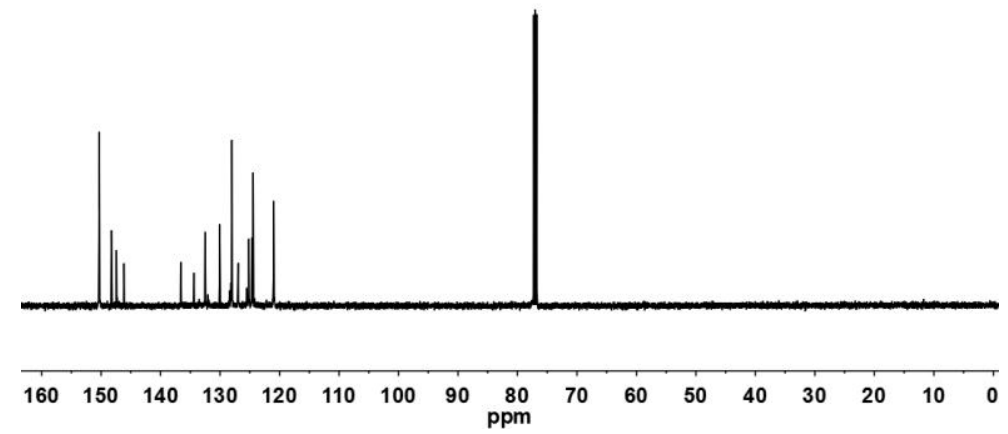

Figure S5. ${ }^{13} \mathrm{C}$ NMR spectrum of $\mathbf{2}$ in $\mathrm{CDCl}_{3}$. 
Single Mass Analysis

Tolerance $=5.0 \mathrm{mDa} /$ DBE: $\min =-150.0, \max =150.0$

Element prediction: Off

Number of isotope peaks used for i-FIT $=3$

Monoisotopic Mass, Even Electron lon

76 formula(e) evaluated with 2 results within limits (all results (up to 1000) for each mass)

$\begin{array}{llll}\text { C: } 20-80 & \text { H: } 20-60 & \text { N: } 0-10 \quad \mathrm{Na}: 0-1\end{array}$

this 3

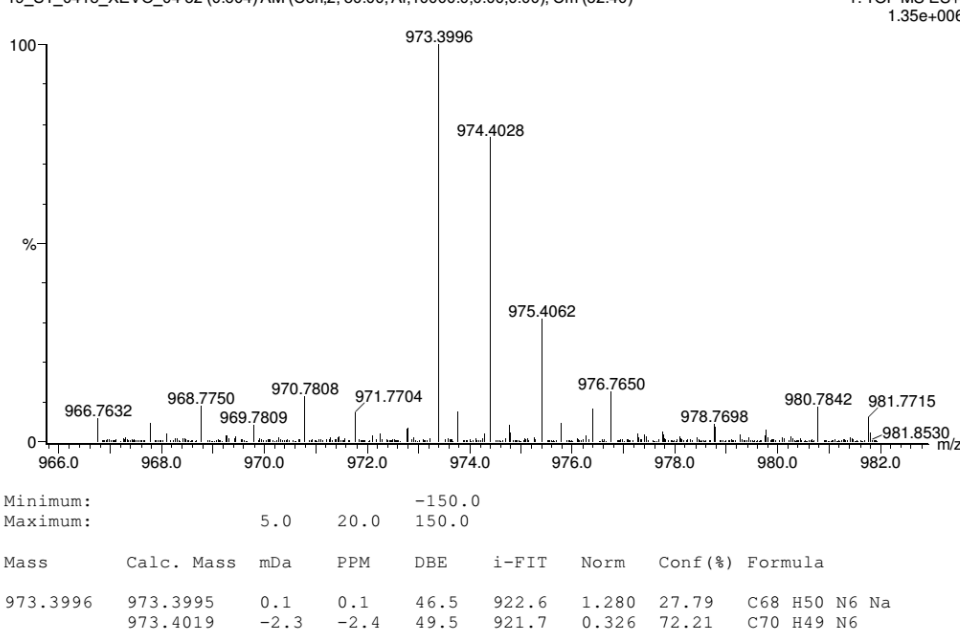

Figure S6. HR-ESI-MS of 2.

Synthesis of 4.

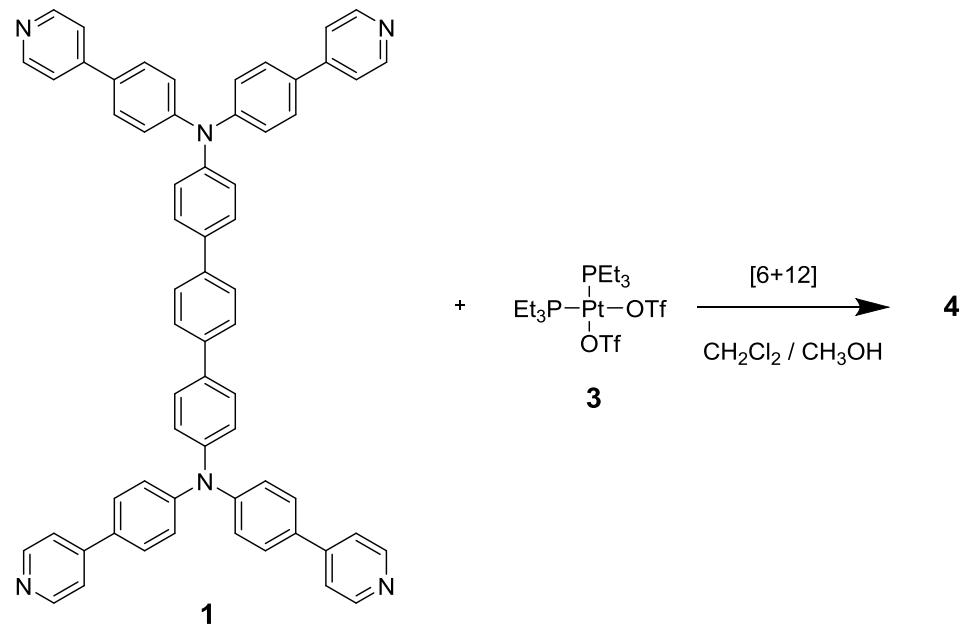

Ligand $1(8.73 \mathrm{mg}, 10.0 \mu \mathrm{mol})$ and $3(14.59 \mathrm{mg}, 20.0 \mu \mathrm{mol})$ were mixed in $\mathrm{CH}_{2} \mathrm{Cl}_{2} / \mathrm{CH}_{3} \mathrm{OH}(2 \mathrm{~mL} / 6 \mathrm{~mL})$. The solution was stirred at room temperature for $10 \mathrm{~h}$ and then concentrated by flushing with $\mathrm{N}_{2}$ gas. The resulting yellow solid was collected without further purification to give compound 4 in quantitative (>99\%) yield. ${ }^{1} \mathrm{H}$ NMR (500 MHz, $\left.\mathrm{CD}_{3} \mathrm{OD}\right): \delta 8.86(\mathrm{~d}, J=6.0 \mathrm{~Hz}, 48 \mathrm{H}), 7.66-7.89$ (m, overlapped, $144 \mathrm{H}), 7.21(\mathrm{~d}, J=6.0,72 \mathrm{H}), 1.96-1.99(\mathrm{~m}$, overlapped, $144 \mathrm{H}), 1.31-1.38(\mathrm{~m}$, 
overlapped, 216H). ${ }^{31} \mathrm{P}\left\{{ }^{1} \mathrm{H}\right\}$ NMR $\left(121.4 \mathrm{MHz}, \mathrm{CD}_{3} \mathrm{OD}\right): \delta 0.39\left(\mathrm{~s},{ }^{195} \mathrm{Pt}\right.$ satellites, $\left.{ }^{1} J_{\mathrm{Pt}-\mathrm{P}}=3063.9 \mathrm{~Hz}\right)$. ESI-TOF-MS calcd for $[\mathrm{M}-7 \mathrm{OTf}]^{7+}(\mathrm{m} / \mathrm{z}): 1850.44$. Found: 1850.46 .

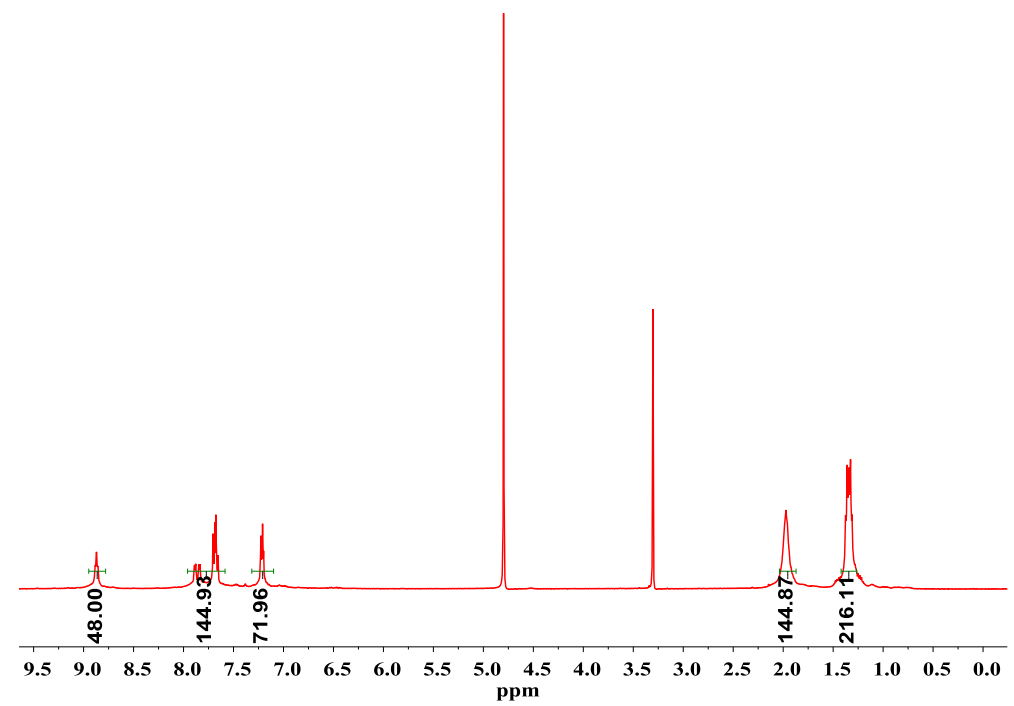

Figure S7. ${ }^{1} \mathrm{H}$ NMR spectrum of $\mathbf{4}$ in $\mathrm{CD}_{3} \mathrm{OD}$.

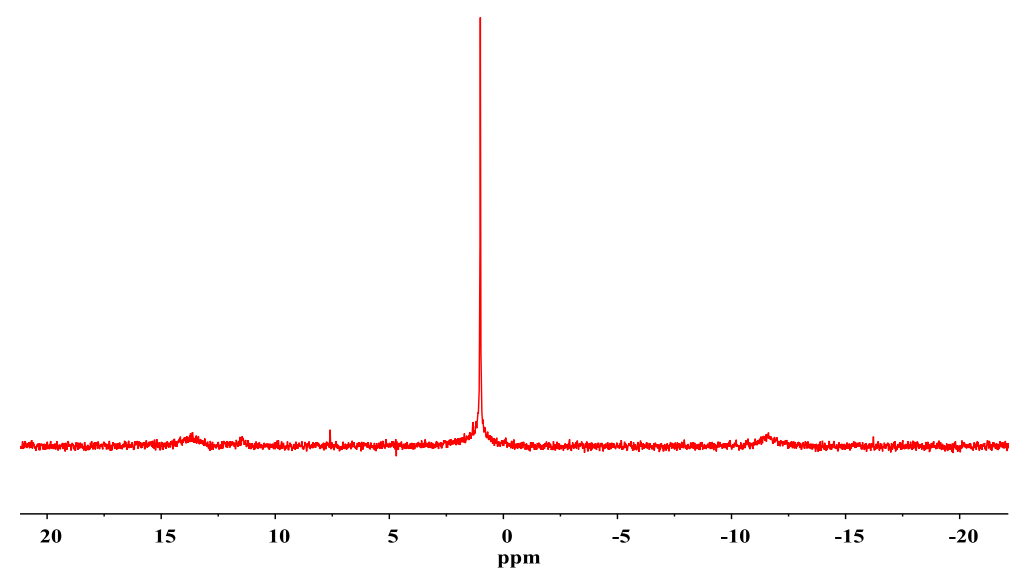

Figure S8. ${ }^{31} \mathrm{P}\left\{{ }^{1} \mathrm{H}\right\}$ NMR spectrum of $\mathbf{4}$ in $\mathrm{CD}_{3} \mathrm{OD}$ at $298 \mathrm{~K}$. 


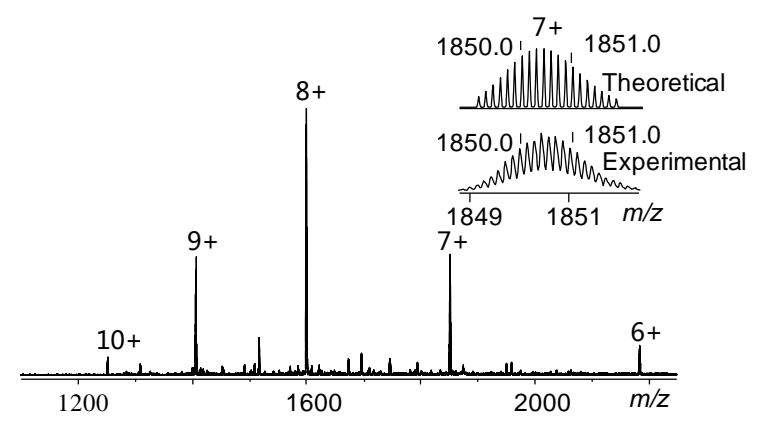

Figure S9. ESI-TOF-MS for compound 4. The insert shows the experimental data (below) and predicted isotope distribution (upper) of $[\mathbf{M}-7 \mathrm{OTf}]^{7+}$.

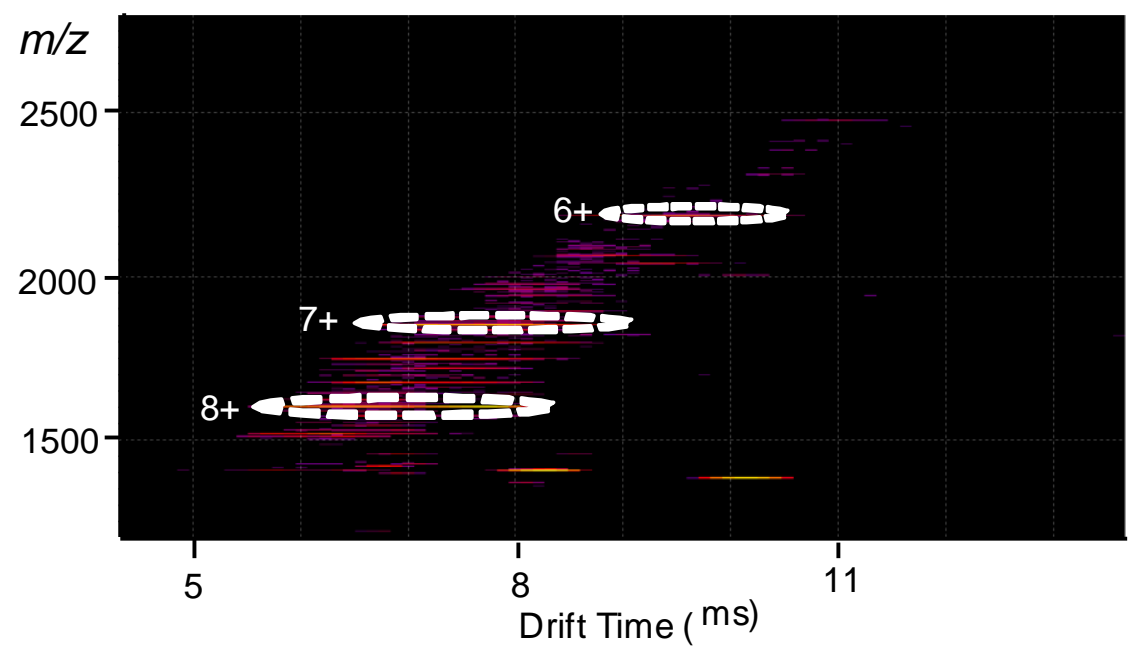

Figure S10. TWIM-MS plot (m/z vs drift time) of 4.

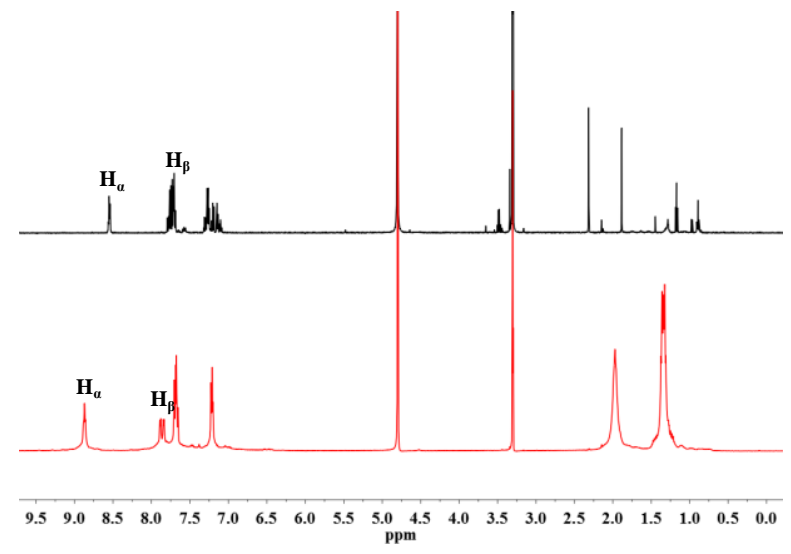

Figure S11. ${ }^{1} \mathrm{H}$ NMR of compounds 1 and 4 in $\mathrm{CD}_{3} \mathrm{OD}$. 


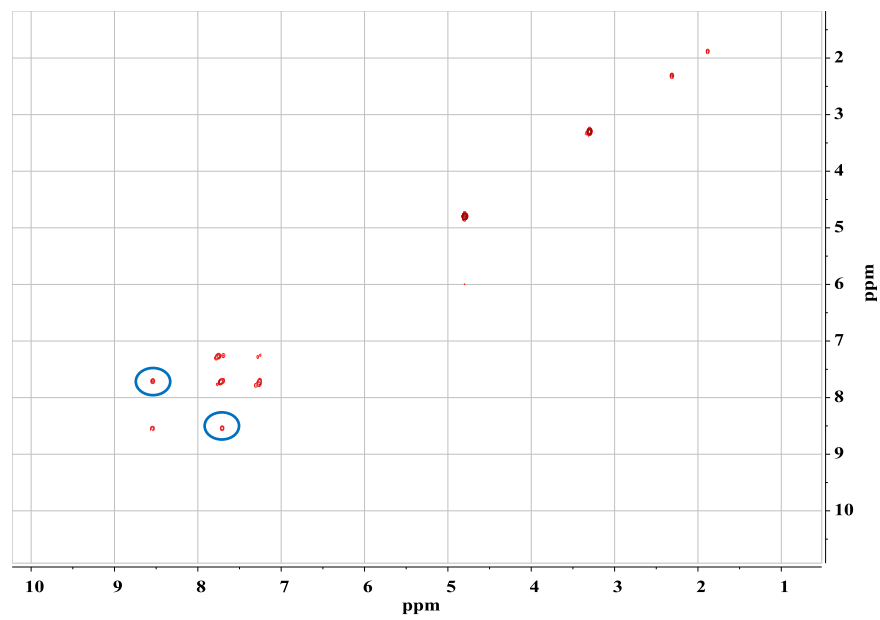

Figure S12. ${ }^{1} \mathrm{H}-{ }^{1} \mathrm{H}$ COSY spectrum of $\mathbf{1}$ in $\mathrm{CD}_{3} \mathrm{OD}$.

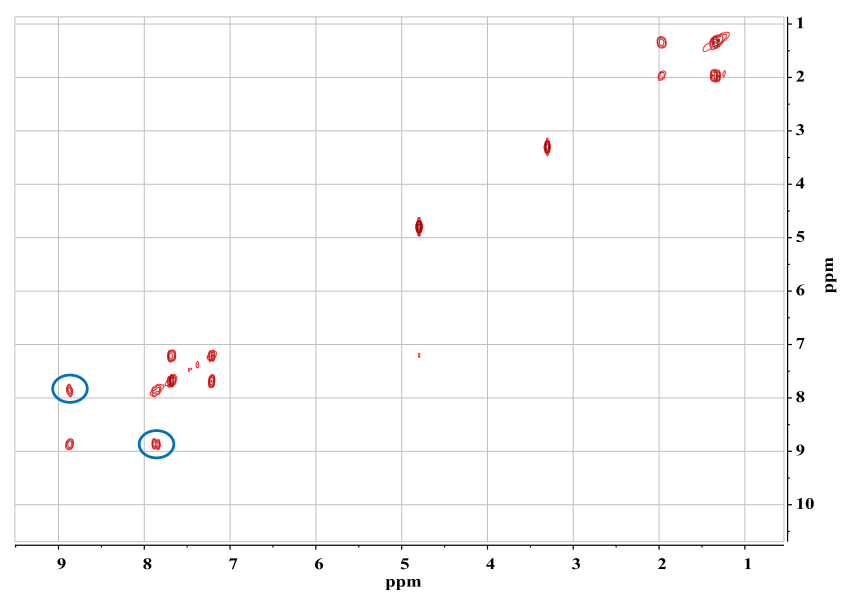

Figure S13. ${ }^{1} \mathrm{H}-{ }^{1} \mathrm{H}$ COSY spectrum of 4 in $\mathrm{CD}_{3} \mathrm{OD}$.

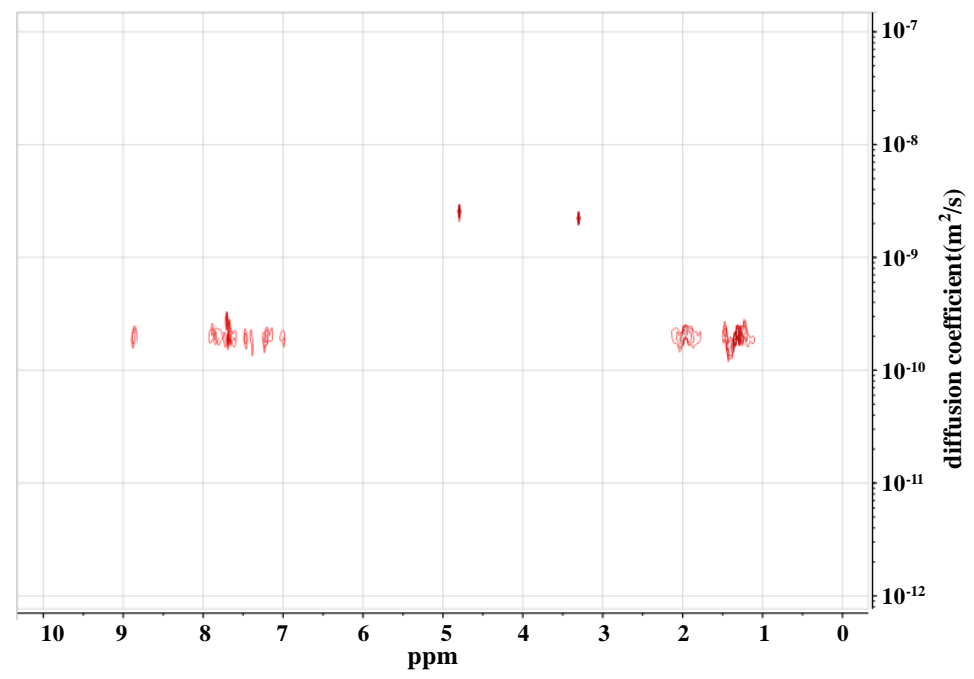

Figure S14. DOSY NMR spectrum of 4 (500 MHz, methanol-d4, $298 \mathrm{~K})$. Diffusion constant D = $1.96 \times 10^{-10} \mathrm{~m}^{2} / \mathrm{s}$. 
Synthesis of 5.

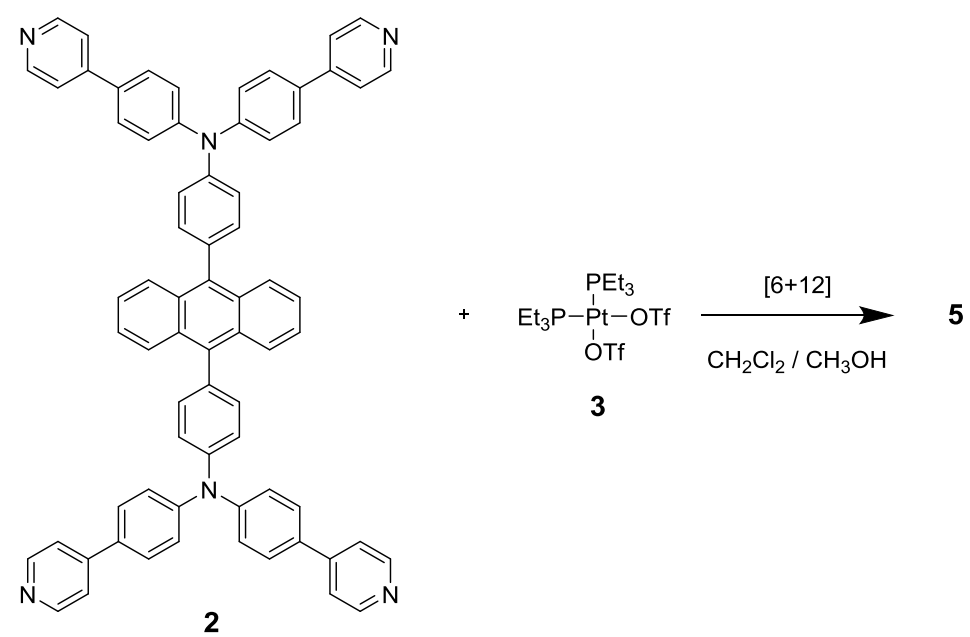

Compound 5 was prepared under the similar procedure for the synthesis of $4 .{ }^{1} \mathrm{H}$ NMR (500 MHz, CD 3 OD): $\delta 8.89$ (d, $J=7.0 \mathrm{~Hz}, 48 \mathrm{H}), 7.85-7.89$ (m, overlapped, $48 \mathrm{H}), 7.73(\mathrm{~d}, J=8.5,48 \mathrm{H}), 7.65-7.67(\mathrm{~m}$, overlapped, $36 \mathrm{H}), 7.33-7.41(\mathrm{~m}$, overlapped, 108H), 1.93-1.96 (m, overlapped, 144H), 1.31-1.38 (m, overlapped, 216H). ${ }^{31} \mathrm{P}\left\{{ }^{1} \mathrm{H}\right\}$ NMR (121.4 MHz, $\left.\mathrm{CD}_{3} \mathrm{OD}\right): \delta 0.53$ (s, ${ }^{195} \mathrm{Pt}$ satellites, ${ }^{1} J_{\mathrm{Pt}-\mathrm{P}}=3070.7$ Hz). ESI-TOF-MS calcd for $[\mathrm{M}-8 \mathrm{OTf}]^{8+}(\mathrm{m} / \mathrm{z}): 1675.05$. Found: 1675.05.

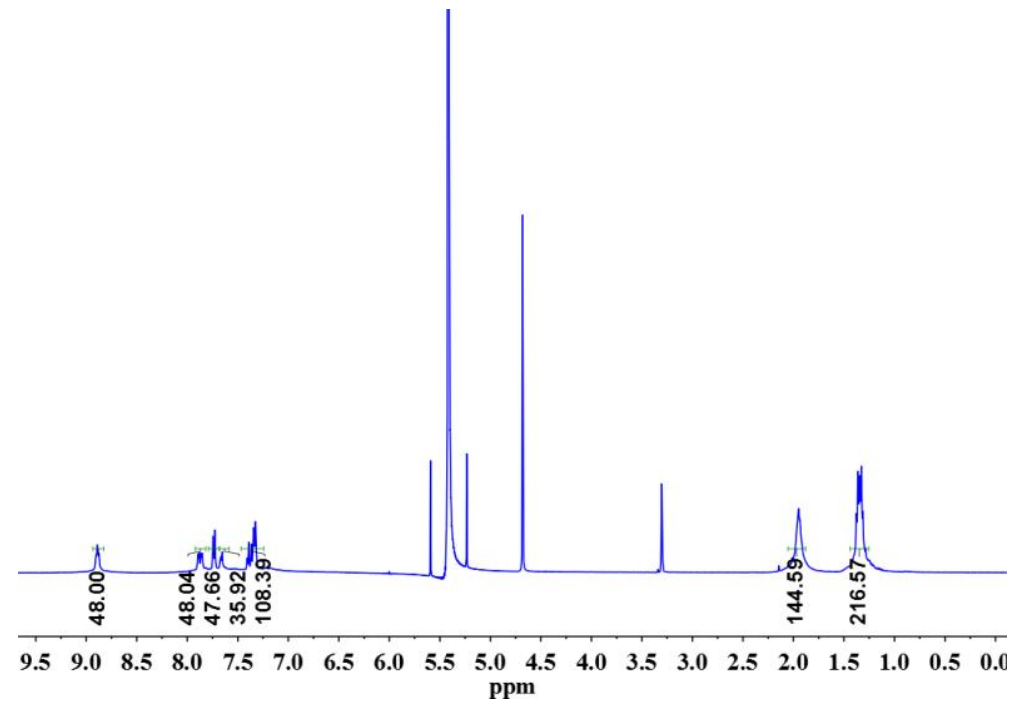

Figure S15. ${ }^{1} \mathrm{H}$ NMR spectrum of $\mathbf{5}$ in $\mathrm{CD}_{3} \mathrm{OD}$ at $298 \mathrm{~K}$. A little amount of dichloromethane was added for improving its solubility. 


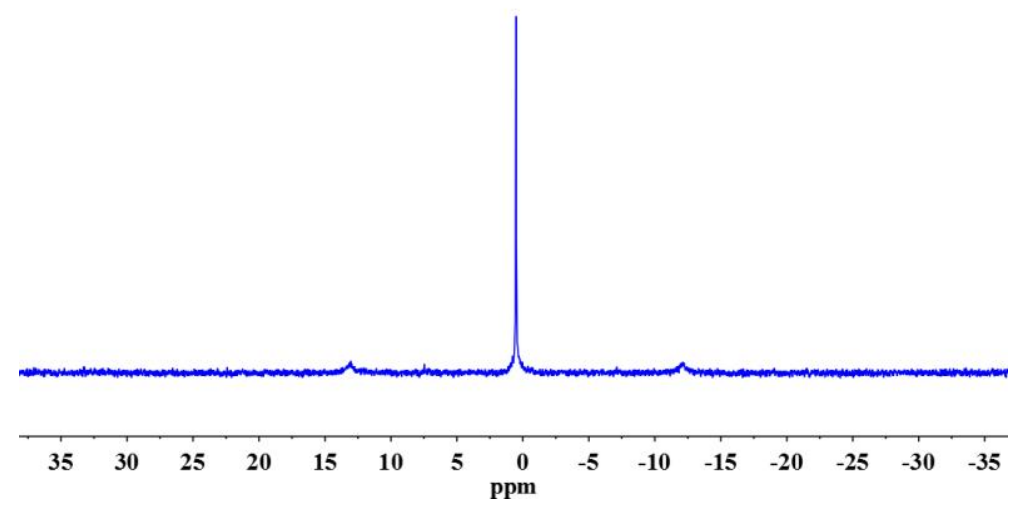

Figure S16. ${ }^{31} \mathrm{P}\left\{{ }^{1} \mathrm{H}\right\}$ NMR spectrum of 5 in $\mathrm{CD}_{3} \mathrm{OD}$ at $298 \mathrm{~K}$. A little amount of dichloromethane was added for improving its solubility.

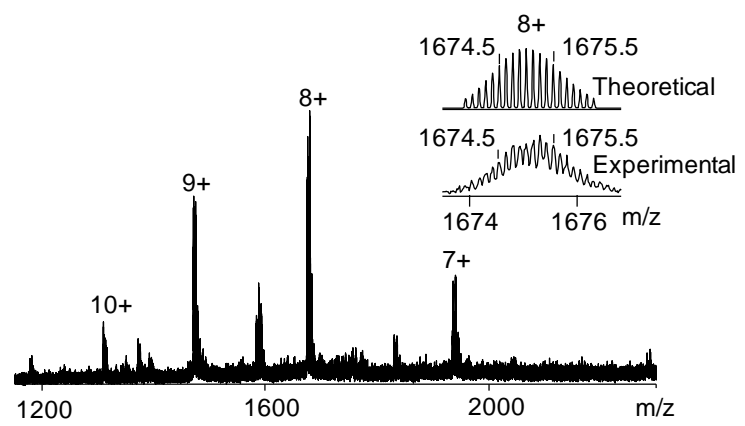

Figure S17. ESI-TOF-MS for compound 5. The insert shows the experimental data (below) and predicted isotope distribution (upper) of $[\mathbf{M}-8 \mathrm{OTf}]^{8+}$.

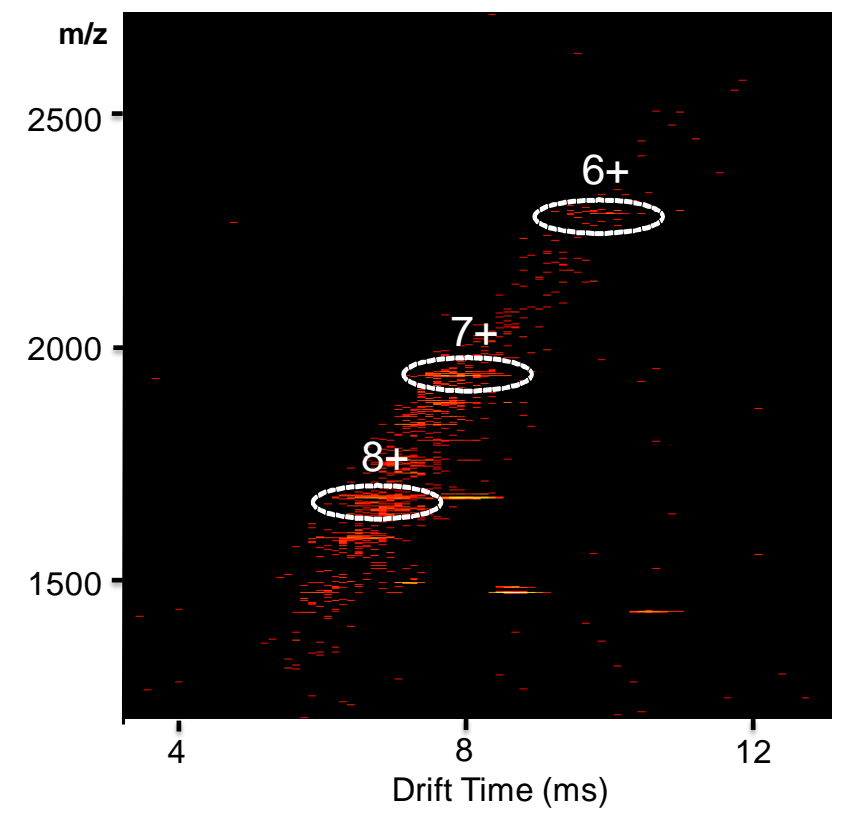

Figure S18. TWIM-MS plot (m/z vs drift time) of $\mathbf{5}$. 


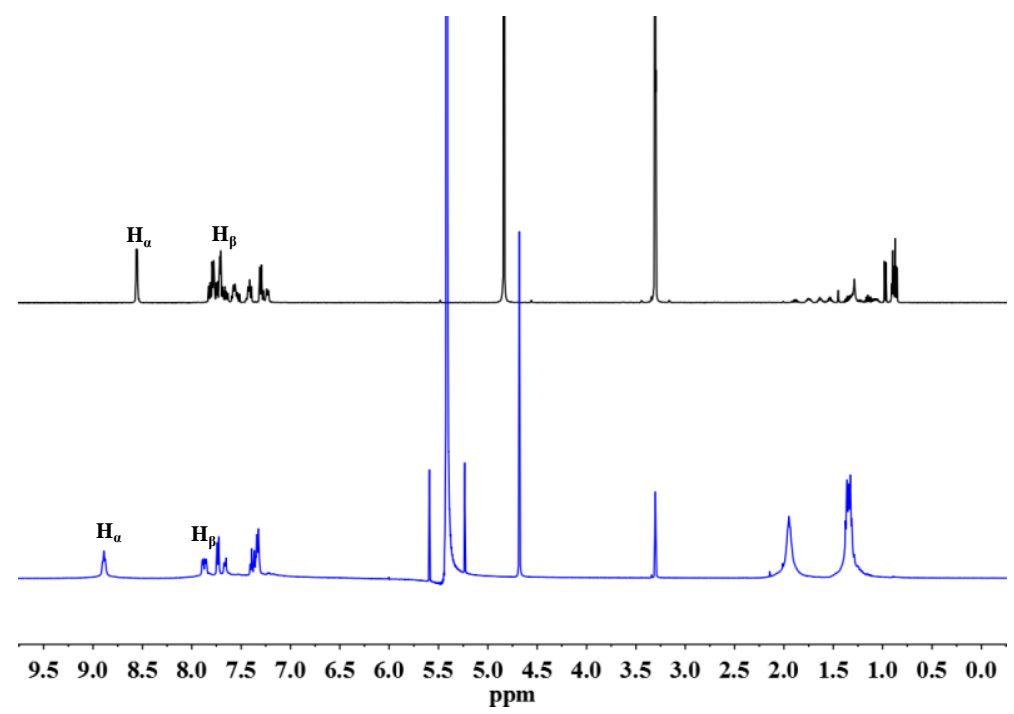

Figure S19. ${ }^{1} \mathrm{H}$ NMR of compounds $\mathbf{2}$ and $\mathbf{5}$ in $\mathrm{CD}_{3} \mathrm{OD}$, whereas the solution of compound $\mathbf{3}$ was added a little amount of dichloromethane for improve its solubility.

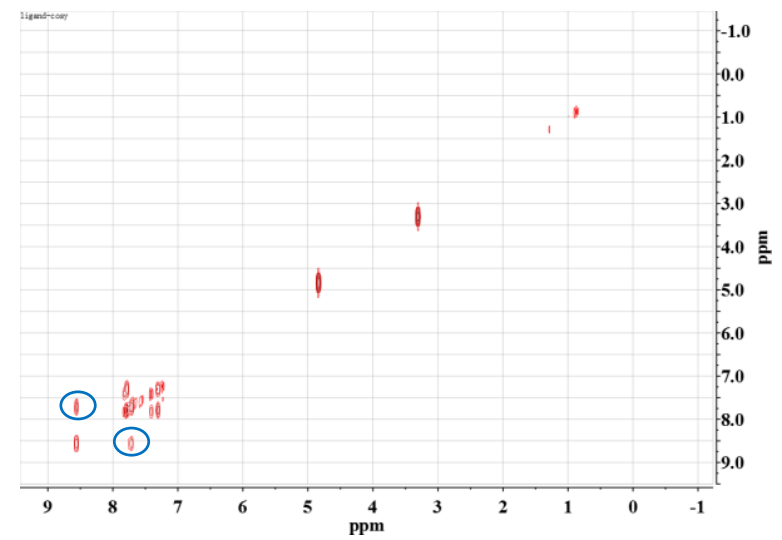

Figure S20. ${ }^{1} \mathrm{H}-{ }^{1} \mathrm{H}$ COSY spectrum of 2 in $\mathrm{CD}_{3} \mathrm{OD}$.

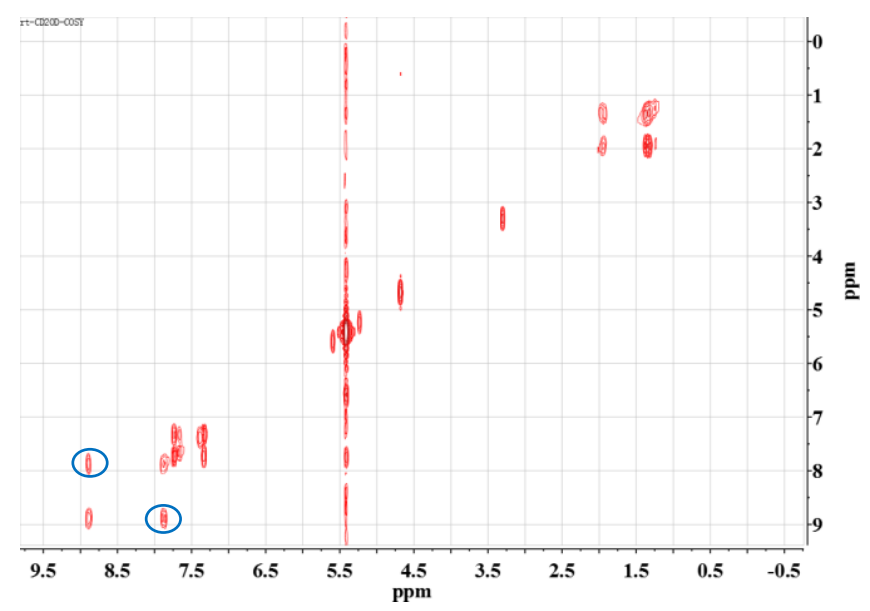

Figure S21. ${ }^{1} \mathrm{H}-{ }^{1} \mathrm{H}$ COSY spectrum of 5. 


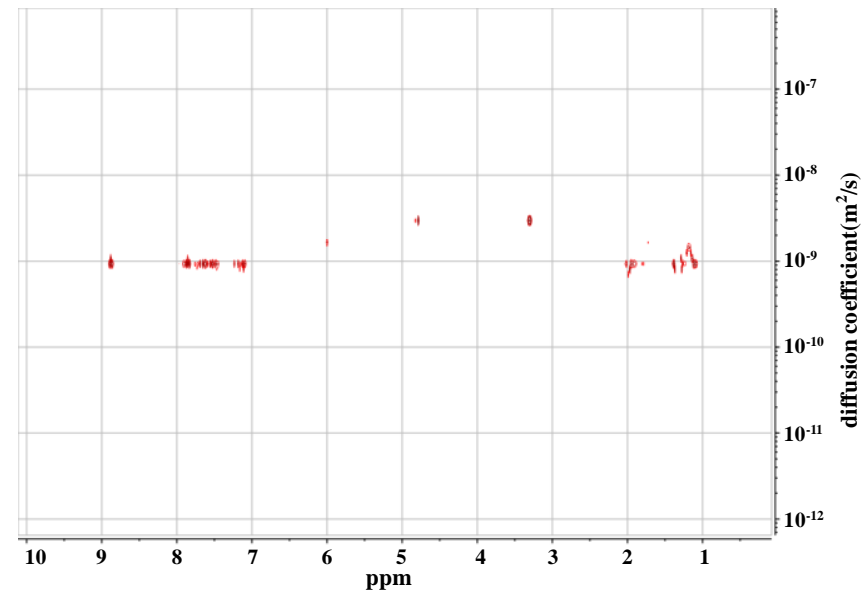

Figure S22. DOSY NMR spectrum of 5 (500 MHz, methanol- $d 4$, $298 \mathrm{~K})$. Diffusion constant D = $9.31 \times 10^{-10} \mathrm{~m}^{2} / \mathrm{s}$.

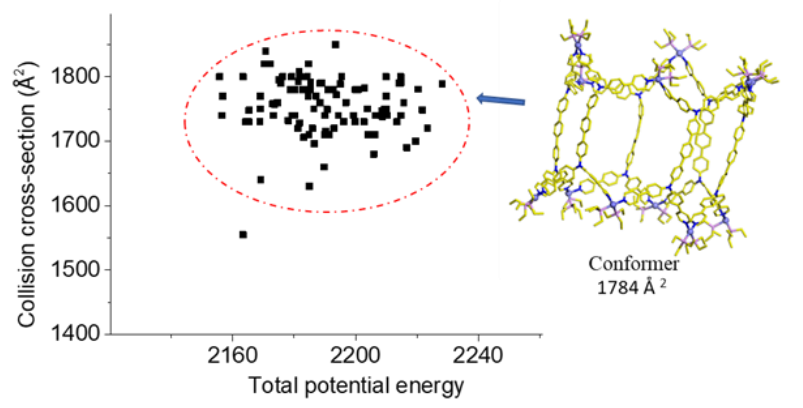

Figure S23. Plot of collision cross-section (CCS) vs. relative energy for 100 candidate structures of $\mathbf{4}$ based on tubular model (conformation 1) by annealing simulations. CCSs were calculated by the TM method using the MOBCAL program. The average TM cross section area of all 100 candidate is $1784 \AA^{2}$.

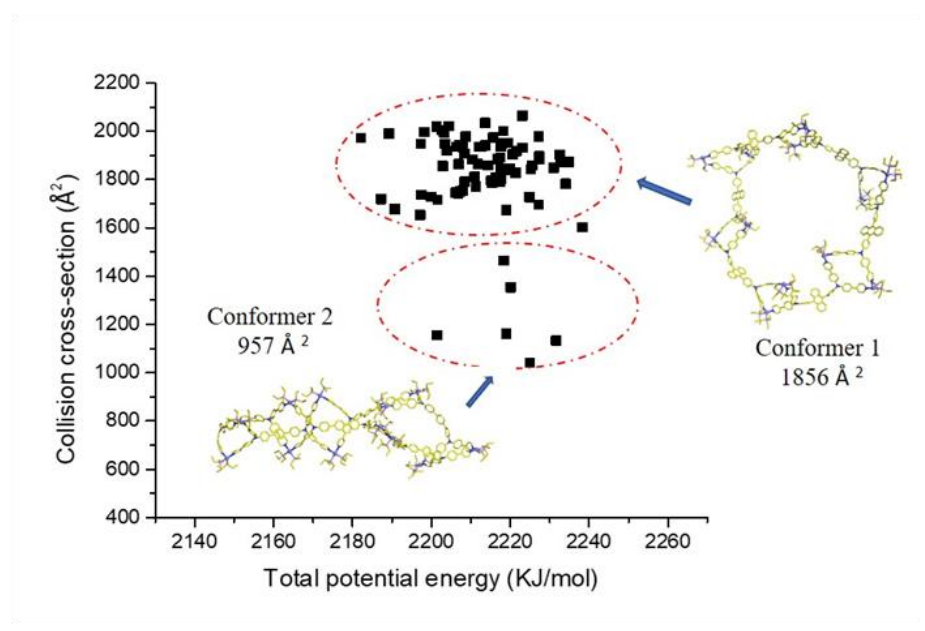


Figure S24. Plot of collision cross-section (CCS) vs. relative energy for 100 candidate structures of $\mathbf{4}$ based on cyclic model (conformation 2) by annealing simulations. CCSs were calculated by the TM method using the MOBCAL program. The average TM cross section area of all 100 candidate is $1685 \AA^{2}$.

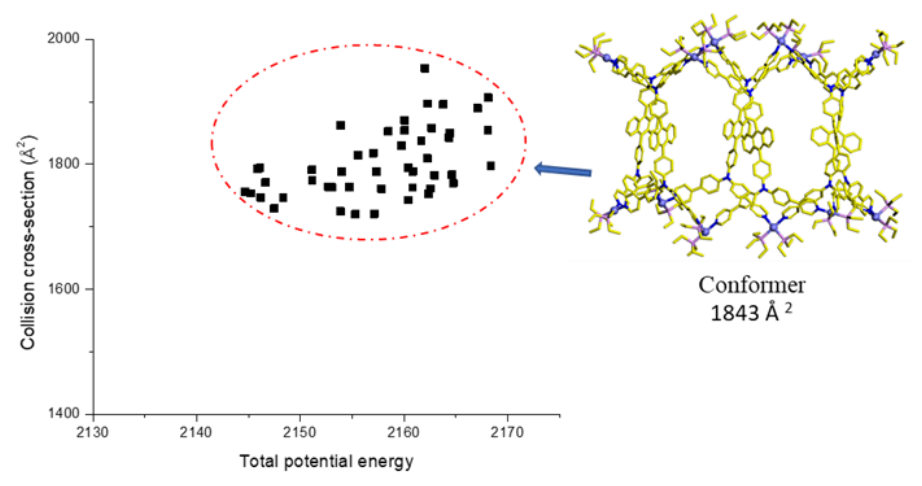

Figure S25. Plot of collision cross-section (CCS) vs. relative energy for 100 candidate structures of 5 based on tubular model (conformation 1) by annealing simulations. CCSs were calculated by the TM method using the MOBCAL program. The average TM cross section area of all 100 candidate is $1843 \AA^{2}$.

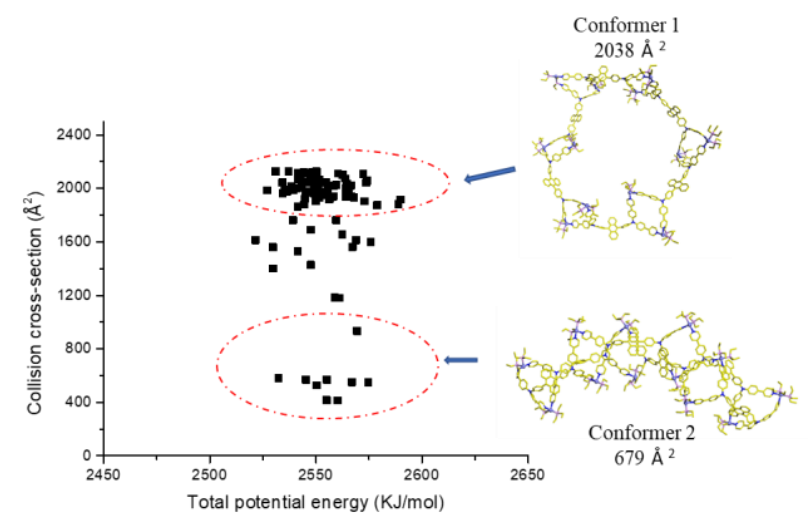

Figure S26. Plot of collision cross-section (CCS) vs. relative energy for 100 candidate structures of $\mathbf{5}$ based on cyclic model (conformation 2) by annealing simulations. CCSs were calculated by the TM method using the MOBCAL program. The average TM cross section area of all 100 candidates is $1806 \AA^{2}$.

\section{Supplementary references}

1. Thalassinos, K. et al. Characterization of phosphorylated peptides using traveling wave-based and drift cell ion mobility mass spectrometry. Anal. Chem. 2008, 81, 248-254.

2. http://www.indiana.edu/ clemmer/Research/Cross\%20Section\%20Database/cs_database.php.

3. Perera, et al. Hexameric palladium (II) terpyridyl metallomacrocycles: assembly with 4, 4'-bipyridine and characterization by TWIM mass spectrometry. Angew. Chem. Int. Ed. 2010, 49,6539-6544. 